\title{
Site Selection and Design of Mini Hydropower Plant for Rural Electrification in Keber River
}

\author{
Shimelash Molla Kassaye*, Tolossa Negassa Ebissa, Bahiru Geleta Gutema, \\ Gutema Tamiru Gurmesa
}

Department of Civil Engineering, Metu University, Metu, Ethiopia

Email address:

shimemolla178@yahoo.com (S. M. Kassaye)

${ }^{*}$ Corresponding author

\section{To cite this article:}

Shimelash Molla Kassaye, Tolossa Negassa Ebissa, Bahiru Geleta Gutema, Gutema Tamiru Gurmesa. Site Selection and Design of Mini Hydropower Plant for Rural Electrification in Keber River. American Journal of Electrical Power and Energy Systems.

Vol. 9, No. 5, 2020, pp. 82-96. doi: 10.11648/j.epes.20200905.12

Received: November 10, 2020; Accepted: November 26, 2020; Published: December 16, 2020

\begin{abstract}
Nearly two billion peoples in developing countries do not have access to electricity service. Renewable energy resources are a best option for rural electrification in a country like Ethiopia where electric light is a luxury enjoyed only by a few peoples. Nowadays, only around fifteen percent of the populations living in urban and semi urban areas are connected to the national grid. The remaining populations are living in scattered rural villages and have very remote chances to get electricity from the grid. The only realistic approach to electrify the rural areas seems therefore to be the off grid or selfcontained system. The contributions of renewable sources of energy like micro/mini or Pico hydro power, to rural electrification are minimal still. The main objective of the present study was to identify the potential of mini hydropower site and proposing a plant for rural electrification in Keber River around Tobacha kebele. So in the research the study starts from the estimation of the design discharge by analyzing of the stream flow using the flow duration curve. For estimating the design discharge the available discharge in the river, the population demand and some guidelines for development of mini hydropower were used. So using the above constraints the power of $120 \mathrm{kw}$ was designed for a 300 households, 1 clinic and 2 elementary schools. Besides estimating the power, the present study focuses on design of civil structures and selection of electromechanical components. Generally the result of the study shows that construction of mini hydropower was feasible in the project site.
\end{abstract}

Keywords: Catchment, Delineation, Discharge, Electrification, Hydrology, Topography Hydropower

\section{Introduction}

\subsection{Background}

In today's time, undoubtedly, electrical energy is becoming an essential commodity for the modern life. Every sector, like industry, technology, transportation, public utilities or the domestic life is now totally dependent on electrical power. The dependence on electrical power is becoming more and more, which has resulted into increasing demand for it [1].

By definition, rural electrification is the process of providing electricity to the households and villages located remotely or located in isolated areas of a country. The need for rural electrification rises because electrification improves the life standard of the humans by uplifting the status of health, education, welfare and technology. The investment for rural electrification is justified over the larger benefits gained by that.

Access to energy is among the key elements for the economic and social development of Ethiopia. The energy sector in Ethiopia can be generally categorized in to two major components: traditional and modern (traditional biomass usage and modern fuels i.e. electricity and petroleum). As more than $80 \%$ of the country's population is engaged in the small-scale agricultural sector and live in rural areas, traditional energy sources represent the principal sources of Energy in Ethiopia.

According to Adejumobi et al (2011) report, rural households utilized the greatest proportion of energy $(>80 \%)$ out of which $99 \%$ is of biomass origin and comprises mainly 
of firewood, charcoal, crop residues, and dung cakes. This biomass energy is most often utilized without being processed, which has many disadvantages to the users including loss of energy due to poor efficiency of utilization and also it may result into health problems. The vast majority of Ethiopian households (93\%) depend on open fire stoves with a very poor fuel efficiency of $10-12 \%$. The household sector, being the major consumer of energy in the country, is putting pressure on the natural ecosystem by devastating the forest resources and compromising food self-sufficiency by taking most of the residues from farms and fields.

The use of renewable source is the most valuable solution to reduce the environmental problems associated with unprocessed bio-mass based energy generation and achieves clean and sustainable energy development. Hydro, wind, biomass, solar and geothermal energy are among the most important renewable sources for energy generation [3].

The sustainable development of hydropower is becoming increasingly important in legislative agenda of the country. The overall objective of the National Hydropower policy is to enhance efficient and sustainable development of the water resources and meet the national energy demands as well as supply for external markets to earn foreign exchange [2].

\subsection{Problem of Statement}

The development of any country depends on the amount of energy consumed. Energy consumption is proportional to the level of economic development. In Ethiopia, the energy consumption per capita is very low and it is almost exclusively generated from biomass and this has a direct impact for the deforestation. The lighting system, in rural areas, use kerosene and it produces emission of pollutants. Furthermore, it has a direct impact on the health of the people.

Ethiopia has a marvellous amount of hydro power potential. Because of the high initial investment cost, it is able to develop only 30 percent of its potential so far. To avoid the electric energy draught, renewable energy technologies like mini/micro hydro power generation, solar photovoltaic and wind turbine can be used to electrify the rural areas. Accordingly in this study, mini hydropower development is going to be dealt for the Keber River around Mettu town.

\subsection{Objectives}

\section{i. General Objectives}

The main objective of the research is to identify the potential of mini hydropower site and proposing a plant for rural electrification around Tobacha kebele in Keber River.

ii. Specific Objectives

1. To develop flow-duration curves for different exceedence levels based on available hydrologic data of the study area which will be used for estimation of discharge for Keber River.

2. To identify Mini hydropower sites based on formulated selection criteria and topographical study.

3. To work out general layout of the proposed scheme; selection of diversion weir and intake site, fore-bay site, penstock alignment, power house site.

4. General design of various components and selection of turbine.

\section{Materials and Methodology}

\subsection{Study Area}

The project site Keber is located in the Tobacha kebele of Mettu woreda. The site is located at a distance of around $5 \mathrm{Km}$ from kemise. The site is connected by road from kemise to Bokoji and is very near to the main road. The stream is a perennial one, but it has more discharge in rainy season because of its large catchment. The catchment of Keber river was identified using the GIS DEM data and is about $359 \mathrm{Km}^{2}$. During the survey, the possible location for weir, fore-bay tank, penstock, turbine, power house were also identified.

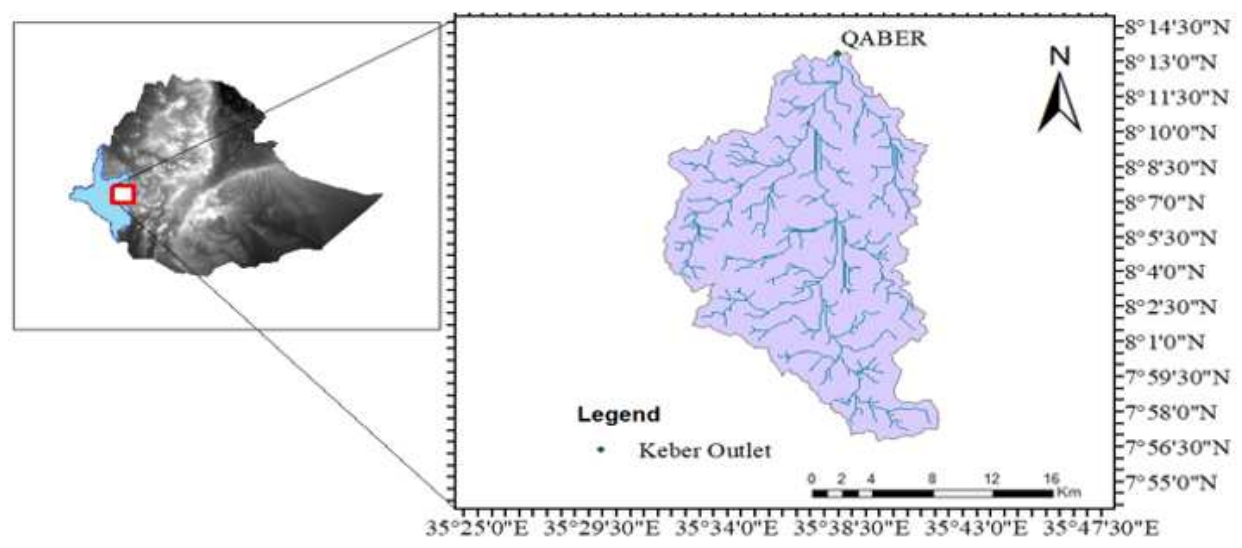

Figure 1. Study area of Keber River in Tobacha kebele.

The main alignment of Keber MHP is to be set up on the right bank of the river. The proposed diversion weir will be located at an elevation of $1671 \mathrm{~m}$ having coordinates $910375 \mathrm{mN} ; 789458 \mathrm{mE}$. The fore-bay will be located at an elevation of $1663 \mathrm{~m}$, defined by coordinates $910544.22 \mathrm{mN}$, $789935.87 \mathrm{mE}$ about $520 \mathrm{~m}$ downstream of the diversion weir along the ridge. The power house will be located at an elevation of $1649 \mathrm{~m}$, defined by coordinates $910543.22 \mathrm{mN}$, 
$789936.87 \mathrm{mE}$ about $540 \mathrm{~m}$ downstream of the diversion weir along the river course.

The site is accessible by vehicle on the road from Kamise to Bokoji around $5 \mathrm{~km}$ from kamise town. These sites are well accessible up to powerhouse site by a footpath on agricultural land and across the ridge to the diversion weir.

The following criteria's had been used to select the site:

1. The selected site should not be very remote.

2. There should be an access to all the components, diversion weir, forebay and powerhouse.

3. The estimated power potential should solve the community's problem.

Catchment Characteristics of the Area

The Keber River is one of the tributary of the Sor River. The monthly maximum temperature is between $24^{\circ} \mathrm{C}$ and $28^{\circ} \mathrm{C}$, and the monthly minimum temperature is between $12^{\circ} \mathrm{C}$ and $14^{\circ} \mathrm{C}$. This river, which arises in the southern part of the catchment, flows to the north and joins the Sor River which in turn joins the Baro River. Flow data recorded near the town of Mettu were used for this study. The dominant soils in the watershed are Eutric Nitisols (70\%), according to FAO/MoWE soil classification [4]. Humic Cambisols also account for $29 \%$ of the soils, and the rest of the watershed consists of Orthic Acrisols and Eutric Cambisols.

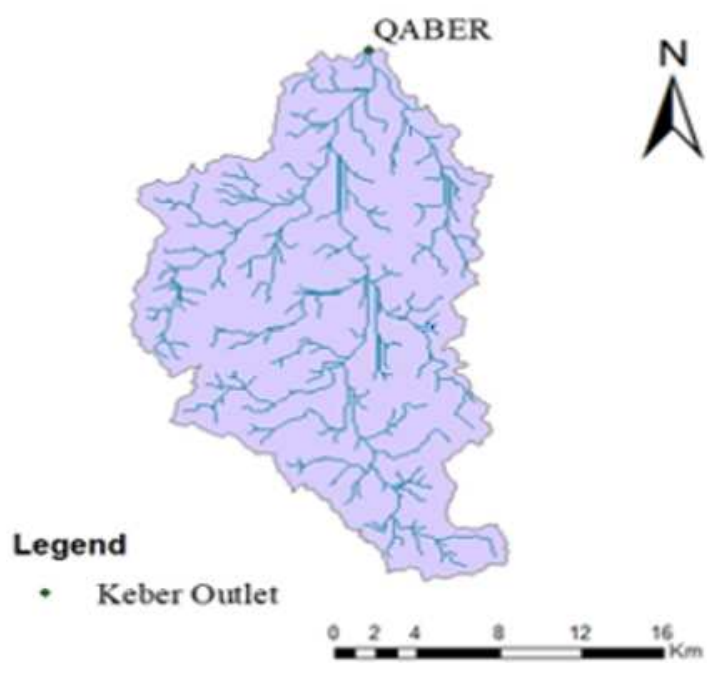

Figure 2. Watershed of Keber River.

\subsection{Hydropower Potential Assessment}

\subsubsection{Watershed Delineation}

The first step in any kind of hydrological modelling is the delineation of streams and watersheds and getting some basic watershed properties such as area, slope, flow length, stream network density etc. The process of delineating watersheds by using DEM is referred to as terrain pre-processing. In this study, the watershed was delineated using the "Hydrology" tool within the Spatial Analyst tools in Arc Toolbox.

So accordingly the watershed of the Keber River was delineated and found covering a watershed area of $359 \mathrm{~km}^{2}$.

\subsubsection{Determination of Head}

The power potential is directly proportional to the discharge and the available Head. For a given site, discharge is mainly controlled by the hydrology and catchment characteristics whereas, head is a function of topography of the area. The term 'Head' is the altitude difference between the fore-bay and the powerhouse site. In other words head is the vertical height from where the water is dropped on the turbine to generate hydropower.

Practically, the total available head is not actually available for the power generation as some of the hydraulic losses occur due to friction in pipe and local constrictions. Therefore, actual head available after head losses is known as 'Net Head' and the head available before the head losses is known as 'Gross head'. The net available head $(\mathrm{H})$ can be estimated as the difference between available geometric head and total head losses from fore-bay to the powerhouse site, equation (1), resulting from simplification of energy equation [5].

$$
\mathrm{H}=\mathrm{Hg}-\Sigma \mathrm{h}
$$

Where, ' $\mathrm{H}$ ' is net head, $\mathrm{Hg}$ is geometrical head and $\mathrm{\Sigma h}$ is total head loss.

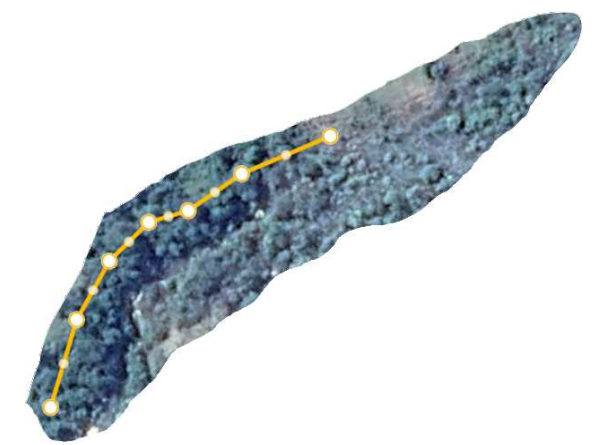

Figure 3. Head difference between the forebay tank and the power house as shown on global mapper.

The total head losses $\Sigma$ h equation (1) from fore bay to the powerhouse site, that could include head losses due to pipe friction $\mathrm{h}_{\mathrm{f}}$ (determine with equation 1$)$ and local constrictions $\mathrm{h}_{\mathrm{L}}$, (losses from trash racks, bends, valves, etc. determine with equation (3)) [6].

$$
\Sigma \mathrm{h}=\Sigma \mathrm{h}+\Sigma \mathrm{h}
$$

Friction losses occur due to friction along water conveyance structures such as pipes or canals; the degree of loss varies according to pipe or canal length and roughness and flow velocity. Lower head losses occur under conditions of smoother shorter conveyance structures, and lower velocity flows. It is determined with equation (3). This is known as Darcy-Weisbach energy loss equation (general form).

$$
\Sigma \mathrm{h}=f \frac{L V^{2}}{2 g d}+\cdots
$$

Where, f-Darcy-Weisbach friction factor (no unit), L length of the pipe $(\mathrm{m}), \mathrm{V}$-mean velocity of flow $(\mathrm{m} / \mathrm{s}), \mathrm{D}$ diameter of the penstock $(\mathrm{m})$, and gravitational acceleration $\left(\mathrm{m} / \mathrm{s}^{2}\right)$.

In addition to friction losses, water flowing through a pipe 
systems experience head losses due to geometric changes at entrances, bends, elbows, joints, racks, valves and at sudden contractions or enlargements of the pipe section. This loss also depends on the velocity and is expressed by an experimental coefficient $\mathrm{K}$ multiplied by the kinetic energy $\mathrm{v}^{2} / 2 \mathrm{~g}$. It is determined with equation (4) [12].

$$
\Sigma \mathrm{h}=K \frac{V^{2}}{2 g}
$$

Where: K- resistance coefficient based on the type of local constriction (no unit), V-mean velocity of flow $(\mathrm{m} / \mathrm{s})$ and gravitational acceleration $\left(\mathrm{m} / \mathrm{s}^{2}\right)$.

For small hydro plants, head losses can be of huge importance to the feasibility of the project and should be thus minimized as much as possible. Accounting for the head losses caused by frictions, entrance, bends, trash rack, exit losses and valve losses should be considered in the computation of design head. A good profile will achieve a uniform acceleration of the flow, minimizing head losses. A proper designed pipeline will have a net head of 85 to $90 \%$ of the gross head measured [7]. In the present study, for power potential assessment gross head has been determined from during the field survey using GPS.

\subsubsection{Hydrological Analysis}

According to Dawit H. M., for the development of any small hydropower scheme an essential first step is to determine whether there is sufficient and reliable amount of water is available to make the scheme economically viable [8]. [9] States that, to estimate water resources as well as hydropower potentials at the sites, hydrologic study needs to be carried out using existing discharge and rainfall data recorded at the gauging stations available for the sub-basin in or nearby the proposed study area. European Small Hydropower Association [10] also states that for ungauged watercourse, where observations of discharge over a long period are not available, it involves the science of hydrology, the study of rainfall and stream flow, and the measurement of drainage basins, catchment areas, evapotranspiration and surface geology for the estimation of discharge.
The hydrological study is the basis for the design of the project, determination of capacity to be installed (design of civil structures and electromechanical equipment), calculation of yearly energy production and statement about the profitability of the plant. Ultimately the economic and overall viability of the project depend on the hydrological analysis.

\section{Flow Duration Curve}

The flow-duration curve is a cumulative frequency curve that shows the percent of time during which specified discharges were equalled or exceeded in a given period [11]. It can be obtained from the hydrograph by organizing the data by magnitude instead of chronologically. The flow duration curve is very useful in hydrologic analysis in general and especially, useful in hydropower studies.

According to Energypedia (2008) the steps to draw flow duration curve from available daily average discharge data are given below:

1. Arranging the flow values (data points) in descending order of their magnitude,

2. Sort (rank) average daily discharges for period of record from the largest value to the smallest value, involving a total of $n$ values.

3. Assigning plotting position exceedance [13] probability) to each data point using Weilbul's formula and

$$
\mathrm{p}=\mathrm{M} /(\mathrm{n}+1) * 100
$$

Where,

$\mathrm{P}=$ Probability that a given flow will be equalled or exceeded ( $\%$ of time)

$\mathrm{M}=$ Ranked position on the listing (dimensionless)

$\mathrm{n}=$ Number of events for period of record (dimensionless)

(iv) Plotting data in a two-dimensional space of flow magnitude versus exceedence probability and joining the resulting points to form a smooth curve.

MS-excel can be used to prepare flow-duration curve. The excel function "RANK" can be used to calculate the rank and the data can be arranged in descending order in Spreadsheet.

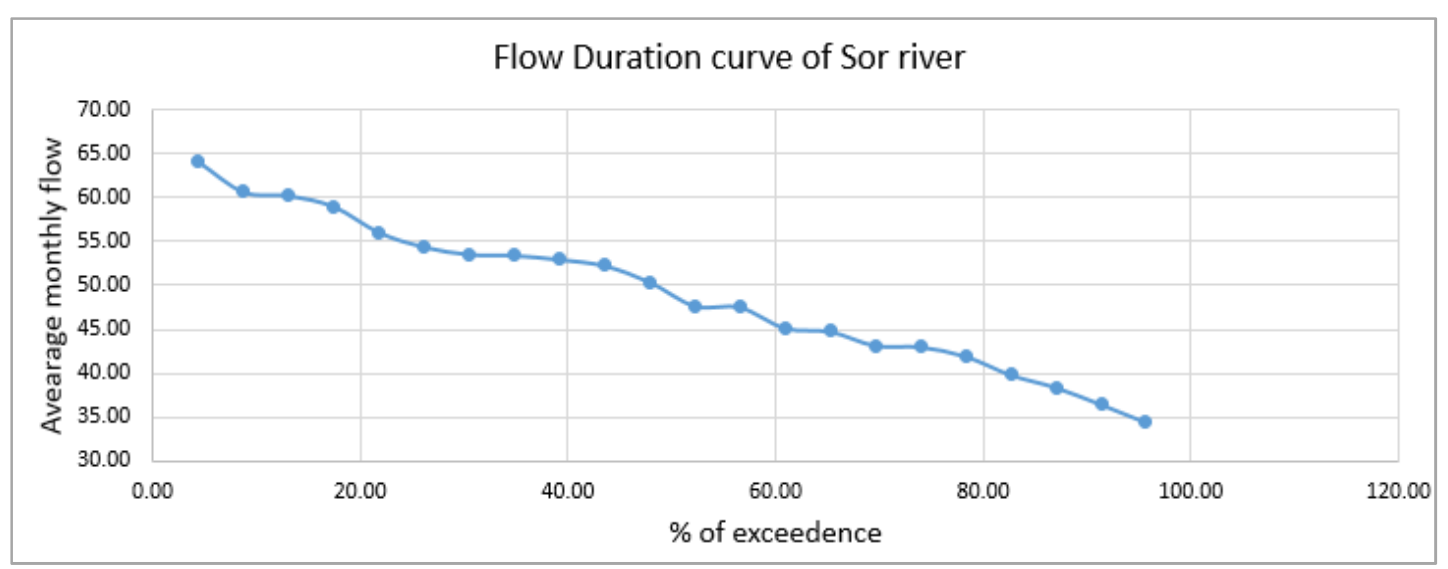

Figure 4. Flow duration curve of Sor River. 
of stream flow data. Unfortunately, most of the hydropower projects especially Micro/Mini hydropower projects are conducted on ungauged river and consequently hydrologists have for a long time used stream flow estimation methods using the mean annual flows to gauge rivers [13]. It is unusual for one of these gauges to be located precisely at the hydro power site of interest. There may however, be a gauging station located on the same river or a downstream river with a drainage area containing the site's watershed.

By flow estimation methods which include the runoff data method, area ratio method and the correlation flow methods approximation for a flow-duration at the un-gauged site can be obtained [14]. Area ratio method is conventionally used to transfer stream flow related information from gauged sites to ungauged sites. The method is useful in obtaining estimates of water availability for hydropower at ungauged sites (especially for small hydropower plants, for run-of-river plants) within the study area [15].

Equation (6) is the common type of relation that is used to estimate flow-duration at an un-gauged site.

$$
\mathrm{Q}_{\mathrm{x}}=\mathrm{q}_{1} ; \mathrm{Q}_{\text {site }}=\text { Qgauge } \cdot \frac{\text { DAsite }}{\text { DAgauge }}
$$

Where;

$\mathrm{DA}_{\text {site }}$ - drainage area of the power plant site $\left(\mathrm{Km}^{2}\right)$

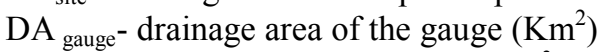

$\mathrm{Q}_{\text {site }}$ - discharge at the diversion site $\left(\mathrm{m}^{3} / \mathrm{s}\right)$

$\mathrm{Q}_{\text {gauge }}$ - discharge at the gauge $\left(\mathrm{m}^{3} / \mathrm{s}\right)$

The above method is applicable if the areas being compared have a similar topography, are close geographically and have a similar precipitation pattern.

So, using the above equation the flow of Keber River was estimated as in table 1 . below. The watershed area of Keber River $359 \mathrm{~km}^{2}$ and that of Sor River was $1622 \mathrm{~km}^{2}$ which was estimated using GIS.

Table 1. Transferring flow data's from Sor River to Keber River.

\begin{tabular}{lll}
\hline Year & Average monthly flow Sor river $\left(\mathbf{m}^{\mathbf{3}} / \mathbf{s}\right)$ & $\mathbf{Q}_{\text {keber }}=\left(\mathbf{A}_{\text {keber }} / \mathbf{A}_{\text {sor }}\right) \mathbf{Q}_{\text {sor }}$ \\
\hline 1985 & 41.94 & 9.23 \\
1986 & 34.38 & 7.56 \\
1987 & 47.56 & 10.46 \\
1988 & 60.73 & 13.36 \\
1989 & 43.17 & 9.50 \\
1990 & 53.60 & 11.79 \\
1991 & 39.82 & 8.76 \\
1992 & 50.43 & 11.09 \\
1993 & 64.18 & 14.12 \\
1994 & 47.70 & 10.49 \\
1995 & 45.16 & 9.94 \\
1996 & 54.43 & 11.98 \\
1997 & 53.01 & 11.66 \\
1998 & 60.32 & 13.27 \\
\hline
\end{tabular}

\begin{tabular}{lll}
\hline Year & Average monthly flow Sor river $\left(\mathbf{m}^{3} / \mathbf{s}\right)$ & $\mathbf{Q}_{\text {keber }}=\left(\mathbf{A}_{\text {keber }} / \mathbf{A}_{\text {sor }}\right) \mathbf{Q}_{\text {sor }}$ \\
\hline 1999 & 53.48 & 11.77 \\
2000 & 59.06 & 12.99 \\
2001 & 52.30 & 11.51 \\
2002 & 38.38 & 8.44 \\
2003 & 36.44 & 8.02 \\
2004 & 43.01 & 9.46 \\
2005 & 44.78 & 9.85 \\
2006 & 56.11 & 12.34 \\
\hline
\end{tabular}

Table 2. Percentage of exceedance for Keber River.

\begin{tabular}{lllll}
\hline Year & Q of keber river & Rank $(\mathbf{n})$ & $\mathbf{n} / \mathbf{( N + 1 )}$ & \% of exceedence \\
\hline 1993 & 14.12 & 1 & 0.0435 & 4.35 \\
1988 & 13.36 & 2 & 0.0870 & 8.70 \\
1998 & 13.27 & 3 & 0.1304 & 13.04 \\
2000 & 12.99 & 4 & 0.1739 & 17.39 \\
2006 & 12.34 & 5 & 0.2174 & 21.74 \\
1996 & 11.98 & 6 & 0.2609 & 26.09 \\
1990 & 11.79 & 7 & 0.3043 & 30.43 \\
1999 & 11.77 & 8 & 0.3478 & 34.78 \\
1997 & 11.66 & 9 & 0.3913 & 39.13 \\
2001 & 11.51 & 10 & 0.4348 & 43.48 \\
1992 & 11.09 & 11 & 0.4783 & 47.83 \\
1994 & 10.49 & 12 & 0.5217 & 52.17 \\
1987 & 10.46 & 13 & 0.5652 & 56.52 \\
1995 & 9.94 & 14 & 0.6087 & 60.87 \\
2005 & 9.85 & 15 & 0.6522 & 65.22 \\
1989 & 9.50 & 16 & 0.6957 & 69.57 \\
2004 & 9.46 & 17 & 0.7391 & 73.91 \\
1985 & 9.23 & 18 & 0.7826 & 78.26 \\
1991 & 8.76 & 19 & 0.8261 & 82.61 \\
2002 & 8.44 & 20 & 0.8696 & 86.96 \\
2003 & 8.02 & 21 & 0.9130 & 91.30 \\
1986 & 7.56 & 22 & 0.9565 & 95.65 \\
\hline
\end{tabular}

III. Mean Annual Flow at Ungauged Sites

From the discussion in the previous sections, it is clear that the evaluation of mean annual flow is necessary for transfer of flow duration curves. When interest focuses to estimate the flow of one site only, then the proportion of mean annual flow at gauge and site (using techniques discussed above) can provide the ratio for the data transfer [14]. However, when estimate has to be made at many ungauged sites, the preparation of a regional flow duration curve is recommended. For the present study, since we have only one gauged station around the first is adopted for the estimation of $75 \%$ dependable discharge data in the river. 


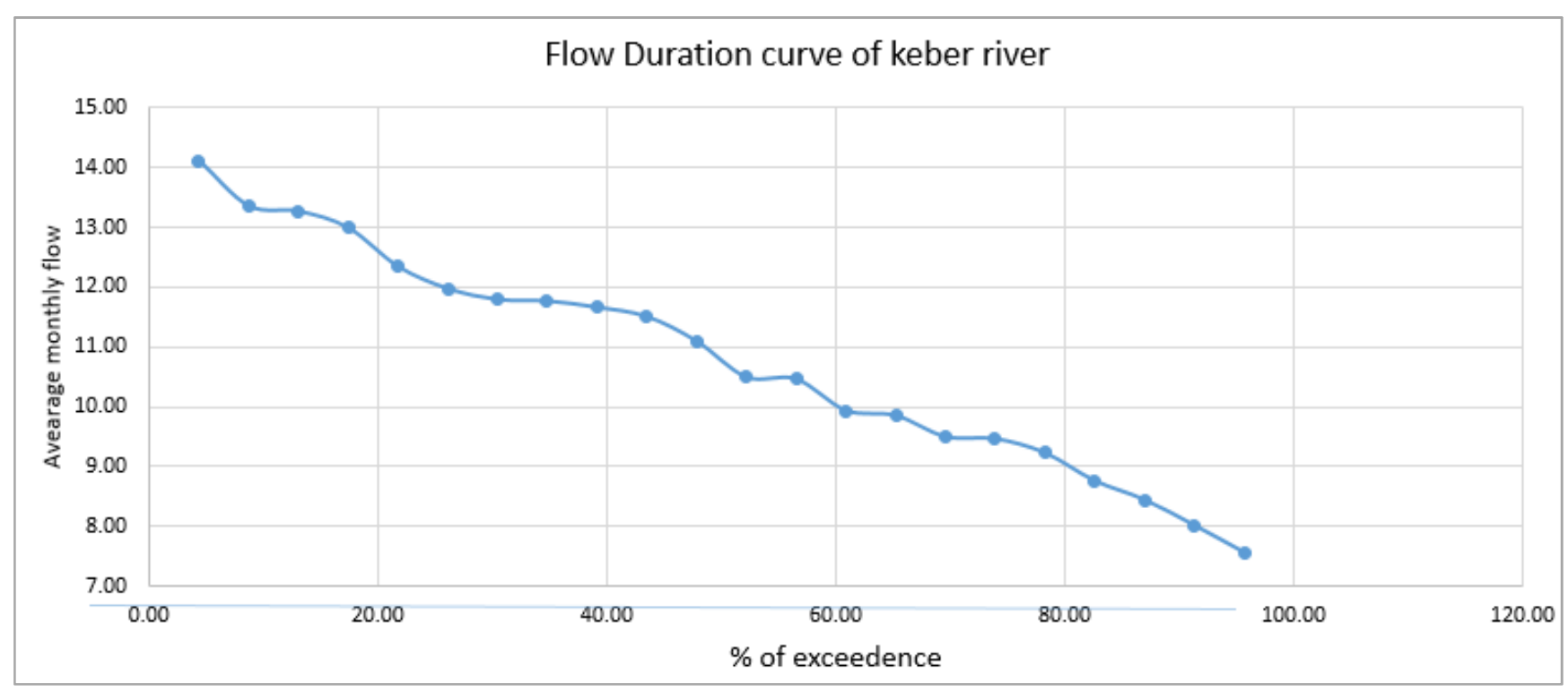

Figure 5. Flow duration curve.

The FDC were used for the selection of design flows.

The potential energy generation depends mainly on available flow and hydraulic head provided by topography. The amount and characteristics of water discharge at a potential SHP site has been evaluated through hydrological analysis. Results from the hydrological analysis, topographical data, and efficiencies of various SHP structures were used to quantify the power potential generation. Basically, the power exploited from hydropower at a particular site is proportional to the product of flow rate and head as given in the following equation.

$$
\mathrm{P}=\frac{\eta \rho g Q H}{1000}
$$

Where;

$\eta$ is the overall energy conversion efficiency (hydraulic to shaft power).

$\rho$ is the density of water,

$\mathrm{g}(\mathrm{m} / \mathrm{s})$ is the acceleration due to gravity,

$\mathrm{Q}(\mathrm{m} / \mathrm{s})$ is the discharge taken equal to $75 \%$ dependable flows, and

$\mathrm{H}(\mathrm{m})$ is Net head

For determining the power potential, the following criteria were considered:

1. The net head is considered as $90 \%$ of the gross head which is a common practice for power potential assessment for desk study level.

2. The efficiency considered for turbines and generators are $90 \%$ and $95 \%$, respectively which combined accounts to the overall efficiency of $85.5 \%$.

3. The downstream release of $10 \%$ at diversion weir site is considered for environmental consideration. Thus, $90 \%$ of available discharge was considered for power potential estimation.

\subsubsection{Estimation of Design Discharge}

In micro/mini-hydro development, the demand will be constant, which is out of relation to weather condition. Therefore, the maximum discharge and firm discharge are almost same in the micro/mini-hydro development [16]. The following figure shows range of unit discharge in each development scale. In the case of mini, the unit discharge is approximately 0.8 to $1.8 \mathrm{~m}^{3} / \mathrm{s} / 100 \mathrm{~km}^{2}$. In this guideline, the range of unit discharge is used for initial evaluation on design discharge as indicator.

Energy Consumption Estimate of Rural Community

Electricity consumption shows large variations depending on climate, culture, reliability of supply, and location. Generally, rural households in developing countries such as Ethiopia have very low electricity consumption, with the primary uses being for lighting and operation of radios, and televisions. An average energy demand estimate, E in $\mathrm{kWh}$, of a given household within a rural setting may be computed using the energy equation described by Foundation Rockfeller [17]. Where $\mathrm{P}_{\mathrm{r}}$ is the wattage rating of a given household appliance (component) in kilowatt $(\mathrm{kW}), \mathrm{t}$ - is the duration for which the appliance is to be operated in hours (h), $\mathrm{n}$ is the number of the appliance. The energy demand estimate has been expressed in $\mathrm{kWh}$ because it is fundamental unit in which quantity of electricity (electric energy) used is measured. One kilowatt-hour is equivalent the amount of work done by one kilowatt of electric power in one hour. Hence, in a rural household where lighting is the only primary use of electricity, for instance, three 60 -watt incandescent lamps used for about five hours each night will have a daily consumption of $0.9 \mathrm{kWh}$ based on equation (1). A radio set and a small fan of wattage ratings $20 \mathrm{~W}$ and $50 \mathrm{~W}$ respectively can be used for 10 hours each day for an additional consumption of 0.2 to $0.5 \mathrm{kWh}$. A small TV set of 120 wattage rating used for 6 hours a day will add a further $0.72 \mathrm{kWh}$. A family could accommodate all these uses easily within a consumption range of $3 \mathrm{kWh}$ daily. For 300 households the total energy consumption becomes 
$900 \mathrm{kwh}$. In addition to this there is electricity consumption for rural health centers and schools. According to Fritz J, average daily consumption for small health clinic in rural area is $10 \mathrm{kwh} /$ day [18].

So based on the flow duration of the keber river above, the demand of the population and the guideline set for the development of the micro/mini hydropower, the design discharge is estimated to be as $1.2 \mathrm{~m}^{3} / \mathrm{s}$.

\subsection{Design and Analysis}

Before discussing the design of primary components of the MHP (Mini Hydro Project), it is necessary first to discuss the preliminary data available through the feasibility survey. The survey team made detailed engineering survey at around summer of 2010 E. C. Detailed measurements were carried out to locate the best position for intake, headrace canal, fore-bay, power-house, tailrace and the weir site. Some of the important parameters that were measured have been used in this study as source of data and are discussed in this section.

Design discharge was taken to be $1.2 \mathrm{~m}^{3} / \mathrm{s}$, after considering the electricity demand of the community, the availability of discharge and the guideline for mini hydropower.

\subsection{Design Parameters of a Mini Hydropower System of Keber River}

\subsubsection{Design of Orifice for Side Intake}

It is known from the feasibility analysis that the design flow of Keber river, $Q=1.2 \mathrm{~m}^{3} / \mathrm{s}$. For the design purpose the velocity of water to pass through the orifice is taken as, $\mathrm{V}=$ $1.3 \mathrm{~m} / \mathrm{s}$. This value was so taken because for MHS (Micro/mini Hydropower System) the recommended velocity through the orifice during normal flow is $(1.0-1.5 \mathrm{~m} / \mathrm{s})$. Based on this premise, it is possible now to calculate the, Area of orifice, $(\mathrm{A})=\mathrm{Q} / \mathrm{V}=1.2 / 1.3=0.8 \mathrm{~m}^{2}$

\subsubsection{Design of Head Race Canal}

The canal type chosen was stone masonry with the cement mortar where the design discharge from the survey data is calculated to be $\mathrm{Q}=1.2 \mathrm{~m}^{3} / \mathrm{s}$. The choice of this material was made because it is recommended that this type of material be used where the type of the soil is porous such as in the case of keber MHP (Mini Hydro Project) construction site. Because choosing other materials such as earthen or stone mud canals had the risk of leading to water seepage through the canal surface that could have caused landslides in the surrounding area. The side slope and roughness coefficients of different types of headrace canal are given as in table below:

Table 3. Side slope and roughness coefficient of different types of head race canals.

\begin{tabular}{|c|c|c|c|}
\hline \multirow{2}{*}{ Material used in the canal } & \multirow{2}{*}{ Side slope $(\mathbf{N}=\mathbf{h} / \mathbf{v})$} & \multicolumn{2}{|c|}{ Max recommended velocity for canals (V) } \\
\hline & & $<0.3 \mathrm{~m}$ depth & $<1$ m depth \\
\hline Stone masonry with mud mortar & $0.5-1.0$ & 1.0 & 1.0 \\
\hline Stone masonry with cement mortar & $0-1.5$ & 1.5 & 1.5 \\
\hline \multicolumn{4}{|c|}{ Roughness coefficient for Masonry Canals } \\
\hline \multirow{2}{*}{ Masonry Canals } & Brickwork & \multicolumn{2}{|c|}{ Roughness coeff ient" $n "=0.015$} \\
\hline & Coarse rubble masonry & \multicolumn{2}{|l|}{0.020} \\
\hline
\end{tabular}

From the table, the roughness coefficient and the side slope of the canal can be easily determined as: roughness coefficient of normal masonry with cement mortar (n) $n=$ 0.017 .

Similarly for this type of canal the side slope $(\mathrm{N})$ is selected to be $=0.5$

$$
\begin{aligned}
& \mathrm{N}=\mathrm{h} / \mathrm{v} \\
& =1 / 2 \\
& =0.5 .
\end{aligned}
$$

With this information and given that $(\mathrm{Q})=1.2 \mathrm{~m}^{3} / \mathrm{s}$, it is now possible to calculate the

Cross sectional area of the headrace canal,

$$
\begin{gathered}
\mathrm{A}=\mathrm{Q} / \mathrm{V} \\
=1.2 / 1.0=1.2 \mathrm{~m}^{2}
\end{gathered}
$$

(Since the maximum recommended velocity for stone masonry with cement mortar is $1.5 \mathrm{~m} / \mathrm{s}$, the velocity is arbitrarily taken to be $1.0 \mathrm{~m} / \mathrm{s}$ )
Now the next objective is to calculate the optimum height of the canal $(\mathrm{H})$, width of the canal bed $(\mathrm{W})$ and the width of the canal top $(\mathrm{T})$. For that, it is first necessary to find $\chi$ which is also the factor used to optimize the canal shape and is given by;

$$
\begin{aligned}
& X=2\left(1+N^{2}\right)-2 \mathrm{~N} \\
& X=2\left(1+0.5^{2}\right)-2 * 0.5
\end{aligned}
$$

$\mathrm{X}=1.5$ (It has no unit because it is a coefficient to optimize the canal shape)

With this information it is possible to calculate the water depth in the canal $(\mathrm{H})$ as follows: $H=\sqrt{(A} /(x+N))$

$$
H=\sqrt{(1.2} /(1.5+0.5))=0.77 \mathrm{~m}
$$

With this information it is possible to calculate the bed width of the headrace canal (B) as follows:

$$
\begin{aligned}
& B=H * X \\
& B=0.77 \times 1.5
\end{aligned}
$$




$$
\mathrm{B}=1.16 \text { meters }
$$

Now in order to calculate the top width of the design water level (T),

$$
\begin{aligned}
& \mathrm{T}=\mathrm{B}+(2 \mathrm{HN}) \\
& \mathrm{T}=1.16+(2 * 0.77 * 0.5) \\
& \mathrm{T}=1.93 \text { meters }
\end{aligned}
$$

It is known from the discussion of design condition that it is necessary to check if

$$
\mathrm{V}<0.8 \mathrm{Vc}
$$

because in order to ensure that the water flows in a stable and uniform flow in the headrace canal the velocity of water must be $80 \%$ less than the critical velocity where critical velocity $\left(\mathrm{V}_{\mathrm{c}}\right)$ is,

$$
\begin{aligned}
& \mathrm{V}_{\mathrm{c}}=\sqrt{ }[\mathrm{Ag} / \mathrm{T}] \\
& =\sqrt{ }[1.2 * 9.8 / 1.93] \text { where } \mathrm{A}=1.2 \mathrm{~m}^{2} \\
& \mathrm{~V}_{\mathrm{C}}=6 \mathrm{~m} / \mathrm{s} \\
& 0.8 \mathrm{Vc}=0.8 \mathrm{~m} * 6=4.8
\end{aligned}
$$

Therefore the velocity of the water $(1.0 \mathrm{~m} / \mathrm{s})$ in the headrace canal is less than $80 \%$ the critical velocity $(4.8 \mathrm{~m} / \mathrm{s})$. Therefore it can be considered that the design of this headrace canal is acceptable.

After determining that the design is acceptable, and calculating the internal canal dimensions now it is necessary to calculate the wetted perimeter of the headrace canal which is given by:

$$
\begin{aligned}
& \mathrm{P}=\mathrm{B}+2 \mathrm{H} \times \sqrt{ }\left(1+\mathrm{N}^{2}\right) \\
& \mathrm{P}=1.16+2 \times 0.77 \sqrt{ }\left(1+0.5^{2}\right) \\
& \mathrm{P}=2.88 \text { meters }
\end{aligned}
$$

After this it is also necessary to calculate the hydraulic radius " $R$ "

To do this we know that

$$
\mathrm{R}=\mathrm{A} / \mathrm{P}
$$

Where, (A) is the cross sectional area of the headrace canal and $(\mathrm{P})$ is the wetted perimeter which was calculated beforehand. Therefore, hydraulic radius " $\mathrm{R}$ "

$$
\begin{gathered}
=1.2 / 2.88=0.466 \\
\mathrm{R}=0.416 \text { meters }
\end{gathered}
$$

Now the final dimension "bed slope" "S" needs to be calculated in order to design the headrace canal and this is given by the Manning's equation. Manning's equation actually relates the flow and velocity of water but it can be applied in this situation as follows.

$$
\mathrm{S}=\left[\mathrm{nV} / \mathrm{R}^{0.667}\right]^{2}
$$

$$
\begin{aligned}
& =\left[0.017 * 1.0 /(0.416)^{0.667}\right]^{2} \\
\mathrm{~S} & =9.3 \times 10^{-4} \\
\mathrm{~S} & =0.00093 \\
\mathrm{~S} & =0.00092=(1: 110)
\end{aligned}
$$

This slope value indicates that a $1 \mathrm{~m}$ of drop in $110 \mathrm{~m}$ of horizontal canal length. Now it is necessary to calculate the head loss in the headrace canal which is given by:

$$
\text { Head Loss }=\text { Lx S }
$$

We know from the survey conducted that the length determined for the headrace canal is 500 meters and we calculated that slope is 0.0008 Therefore,

$$
\text { Head Loss }=500 \times 0.00093=0.465 \text { meters }
$$

Now it is necessary to check for the size of the largest particle that can travel through the canal. This is necessary because beyond a certain size of particle, it is not desirable that they would pass through the canal,

$$
\mathrm{d}=11 \mathrm{RS}
$$

$$
=11 \times 0.416 \times 0.00093=0.0041 \mathrm{~m}=4.25 \mathrm{~mm}
$$

The particle larger than $4.25 \mathrm{~mm}$ would settle in this headrace canal. Therefore, to avoid deposition upstream of the settling basin, the gravel trap must be designed to remove all particles greater than $4.25 \mathrm{~mm}$.

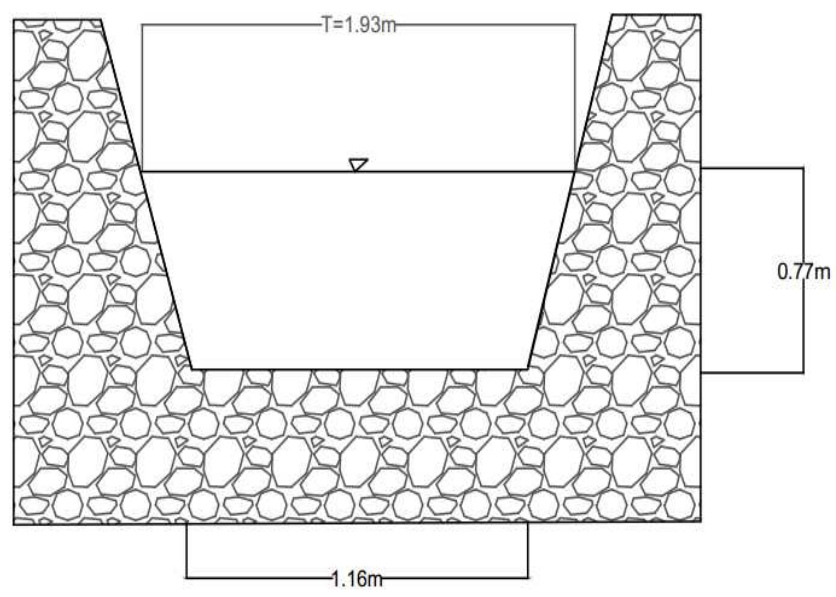

Figure 6. Illustrates the design of the headrace canal in auto CAD by putting in the above calculated dimensions.

\subsubsection{Design of Penstock Pipe}

The following factors have to be considered when deciding which material to use for a particular penstock: surface roughness, design pressure, method of jointing, weight and ease of installation, accessibility of the site, terrain, soil type, design life and maintenance, weather conditions, availability, relative cost, likelihood of structural damage.

In the design of the penstock pipe, the first step is to choose the material for the penstock pipe. For that, the best choice is thought to be of mild steel, as they can withstand 
high pressure, are cheap to get and in case where several joints are required they are the easiest to manage [19]. As discussed already in the design parameters, the table below which is reproduced again, showed the comparison of different materials:

Table 4. Comparison of different materials for selection of penstock pipe.

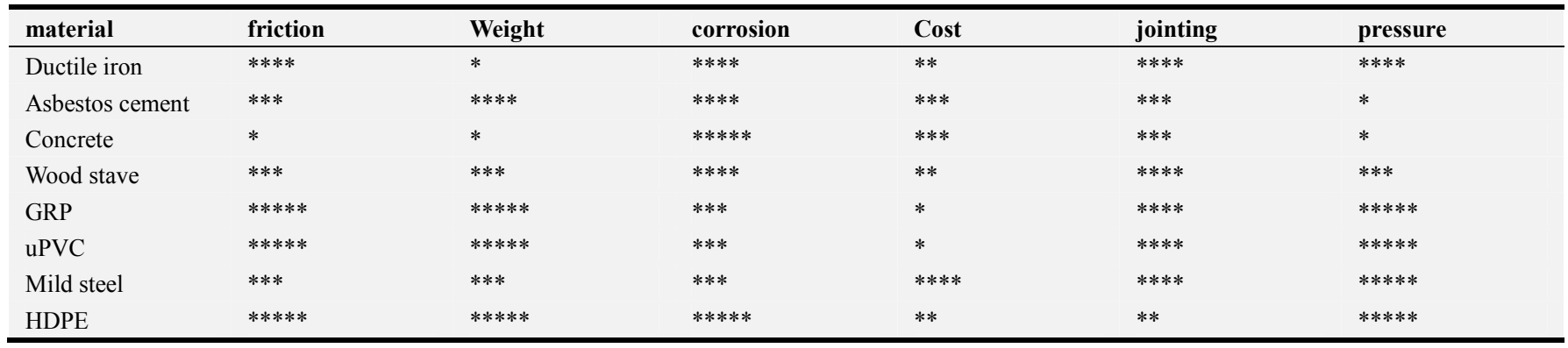

$*=$ poor,$* * * * *=$ Excellent

After selecting the material for the penstock pipe, which was chosen as mild steel, it is necessary to determine its diameter. The most important design parameter in this selection is that the velocity of the water should be in between $2.5 \mathrm{~m} / \mathrm{s}$ and $3.5 \mathrm{~m} / \mathrm{s}$. If the velocity is lower or higher it can cause loss in the power output and thus be uneconomical in the longer run. The equation for determining the diameter of the pipe is given by:

$$
\text { Dpipe }=\sqrt{\left(\frac{4 Q}{\pi V}\right)}
$$

Where,

$\mathrm{d}_{\text {pipe }}=$ inside diameter of the pipe (m)

$\mathrm{Q}=$ design flow $\left(\mathrm{m}^{3} / \mathrm{s}\right)$

$\mathrm{V}=$ average velocity in the pipe $(\mathrm{m} / \mathrm{s})$

In this specific case, since the pipe is a long set type, $\mathrm{V}=$ $2.7 \mathrm{~m} / \mathrm{s}$ was chosen to minimize the head loss. (From design parameters it was recommended that velocity of water $\mathrm{V}$ be somewhere between $2.5 \mathrm{~m} / \mathrm{s}$ and $3.5 \mathrm{~m} / \mathrm{s}$ to optimize the velocity)

$$
\text { Dpipe }=\sqrt{\left(\frac{4 * 1.2}{\pi * 2.7}\right)}=0.75 \mathrm{~m}=750 \mathrm{~mm}
$$

After selecting the material and the diameter of the penstock pipe it is necessary to calculate the head loss in the pipe length which is given as;

Total head loss $=$ major head loss $(\mathrm{hf})+$ minor head loss $\left(\mathrm{H}_{\text {minor }}\right)$ where;

Major Head loss (hf)

$$
h f=\frac{f \cdot L \cdot V^{2}}{2 \cdot g \cdot d_{\text {pipe }}}
$$

Where,

$\mathrm{f}=$ friction factor for pipe material, dimension less

$\mathrm{L}=$ length of pipe in meters

$\mathrm{V}=$ Average velocity inside pipe, $\mathrm{m} / \mathrm{s}$

$\mathrm{d}_{\text {pipe }}=$ the inside pipe diameter, meters

Now in this situation; $\mathrm{f}=0.0014$ (from Moody Chart), Length chosen for the pipe was $22 \mathrm{~m}$ from the survey.
Average velocity inside pipe is chosen as $2.7 \mathrm{~m} / \mathrm{s}$ and the diameter of the pipe from calculation were found out as 750 $\mathrm{mm}$ or $0.75 \mathrm{~m}$, therefore;

$$
h f=\frac{0.0014 \times 20 \times 2.7^{2}}{2 \times 9.81 \times 0.75}=0.013 \mathrm{~m}
$$

Now in order to calculate the total head loss it is also necessary to calculate the minor head loss which is given by;

$$
\begin{gathered}
\text { Minor head loss }\left(\mathrm{h}_{\text {minor }}\right)=\mathrm{v}^{2}\left(\mathrm{~K}_{\text {entrance }}+\mathrm{K}_{\text {bend }}+\mathrm{K}_{\text {contraction }}+\right. \\
\left.\mathrm{K}_{\text {valve }}\right) / 2 \mathrm{~g} \\
\mathrm{~K}_{\text {entrance }}=0.2 \\
\left.\mathrm{~K}_{\text {contraction }}=0 \text { (not available in this case }\right) \\
\left.\mathrm{K}_{\text {valve }}=0 \text { (not available in this case }\right) \\
\mathrm{K}_{\text {bend }}=0.34 \\
\text { Minor head losses, } \mathrm{h}_{\text {minor }}=\left[\mathrm{v}^{2} / 2 \mathrm{~g}\right] \times\left(\mathrm{K}_{\text {entrance }}+\mathrm{K}_{\text {bend }}+\right. \\
\left.\mathrm{K}_{\text {contraction }}+\mathrm{K}_{\mathrm{valve}}\right) \\
=\left[2.7^{2} / 2 * 9.81\right] \times(0.2+0.34+0+0) \\
=0.2 \mathrm{~m}
\end{gathered}
$$

Now the total head loss can be calculated $=0.2 \mathrm{~m}+0.013$ $\mathrm{m}=0.213 \mathrm{~m}$

Although, it was not possible to design and show penstock pipe to scale; the representative figure was designed in auto $\mathrm{CAD}$ and is presented in figure 7.

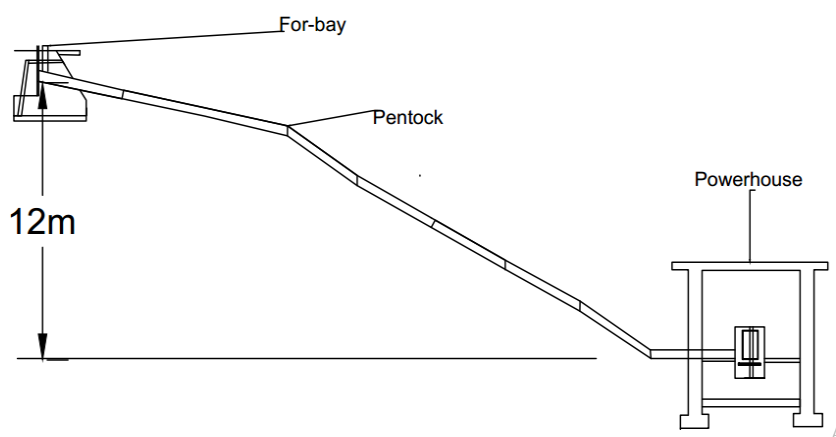

Figure 7. Design of the penstock pipe (AutoCAD). 
Similarly, although calculating the dimensions of numerous anchor blocks to support the penstock assembly was not feasible, the representative design of an anchor block from auto $\mathrm{CAD}$ is shown in figure 8 below.

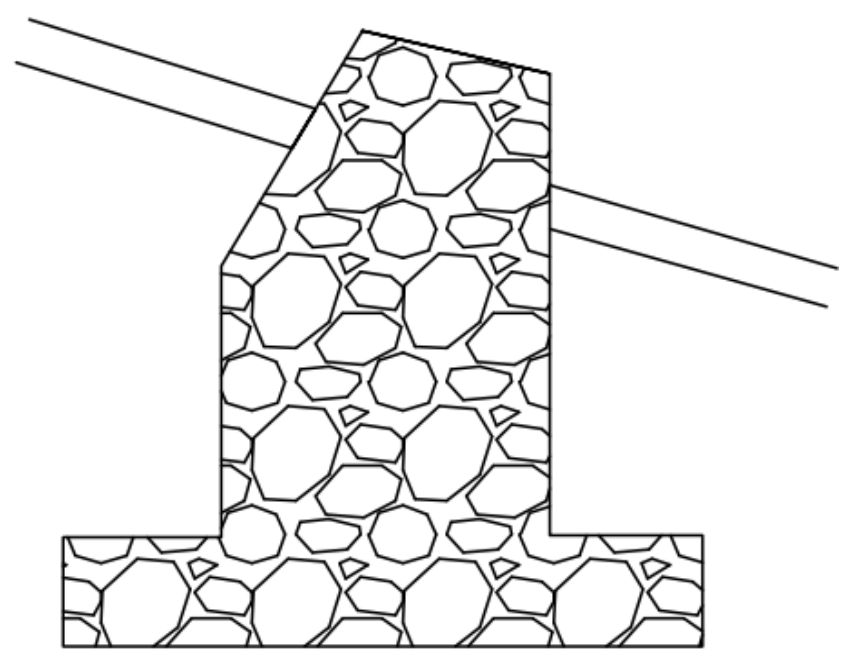

Figure 8. Anchor blocks designed to support penstock pipes in vertical and horizontal bends to support the structure (AutoCAD).

\subsubsection{Design of the Fore Bay Tank (Settling Basin)}

The fore bay tank forms the connection between the channel and the penstock. The main purpose is to allow the last particles to settle down before the water enters the penstock. Depending on its size it can also serve as a reservoir to store water. A sluice will make it possible to close the entrance to the penstock. In front of the penstock a trash rack need to be installed to prevent large particles to enter the penstock.

While designing the settling basin the following criteria have to be satisfied.

1. The dimensions of the basin (length and width) must be large enough ensure that the sediments can settle but not be so large that the structure is too massive and therefore too expensive.

2. A proper settling area must avoid flow turbulence and flow separation caused by sharp bends and area changes.

3. Enough space must be available to collect sediment.

4. It must be possible to easily flush the deposits at sufficiently intervals.

5. Water which exits the flush gate must be led away from the basin and penstock foundations. Otherwise the soil supporting the installations will be flushed away. A paved spillway drain with walls should be built.

For the design of settling basin, the first step is to choose arbitrarily the suitable width of the settling basin. The rule of thumb says that it should be two to five times the width of the headrace canal; we know that the width of the headrace canal from calculations before is $1.16 \mathrm{~m}$. The width of the settling basin (W) was chosen as $3.5 \mathrm{~m}$ which is about four times the width of the headrace canal and is therefore allowed, so we have $\mathrm{W}=3.5 \mathrm{~m}$, ( $\mathrm{Q}$ or $\left.\mathrm{Q}_{\text {gross }}\right)$ or the design flow is $1.2 \mathrm{~m}^{3} / \mathrm{s}$. It is known that in order to calculate the settling length $\left(\mathrm{L}_{\text {forebay }}\right)$ of the settling basin the following equation is given,

$$
\mathrm{L}_{\text {forebay }}=2 \mathrm{Q} /\left(\mathrm{Wx} \mathrm{V}_{\text {vertical }}\right)
$$

$\mathrm{V}_{\text {vertical }}$ refers to the fall velocity taken as $0.03 \mathrm{~m} / \mathrm{s}$ for example, for the value of particle of the size $0.3 \mathrm{~mm}$. The same value will be taken in this case also,

The value (W) is arbitrarily chosen to be $3.5 \mathrm{~m}$; $\mathrm{Q}_{\text {gross }}=1.2$ $\mathrm{m}^{3} / \mathrm{s}$ and $\mathrm{V}_{\text {vertical }}=0.03 \mathrm{~m} / \mathrm{s}$

With this, following information can be obtained;

$$
\begin{gathered}
\mathrm{L}_{\text {forebay }}=2 \mathrm{Q} /\left(\mathrm{Wx} \mathrm{V}_{\text {vertical }}\right) \\
=(2 \times 1.2) /(3.5 \times 0.03)=20 \mathrm{~m}
\end{gathered}
$$

Therefore the length of the settling basin is $20 \mathrm{~m}$. As the design parameter showed, the length of the settling basin should be four to 10 times of its width.

Here length $=20 \mathrm{~m}$ which is $20 / 3.5=5.67$; which is almost six times the width. Hence, the design is acceptable.

Again the fore bay tank has to be designed with a trash rack and an opening to penstock pipes. The most important element to be calculated in the design of the fore bay tank is the submergence head. The submergence head or the depth of water above penstock pipe, should fulfil the criteria (Submergence head) hs $>=1.5 \mathrm{~V}^{2} / 2 \mathrm{~g}$

Where, $\mathrm{V}$ refers to the velocity of water in the penstock, which in this case is $2.5 \mathrm{~m} / \mathrm{s}$;

Therefore,

$$
\begin{gathered}
\mathrm{Hs}>=1.5 \mathrm{~V}^{2} / 2 \mathrm{~g} \\
\mathrm{Hs}>=1.5 \times 2.5^{2} / 2 \times 9.8 \\
\mathrm{hs}>=0.48 \mathrm{~m}
\end{gathered}
$$

In other words, the submergence head of the fore bay tank should be 0.48 meters.

Similarly while designing the fore bay tank it is also necessary to construct the diameter of the air vent or $d_{\text {airvent }}$ which is given as,

$$
\mathrm{d}^{2} \text { airvent }=\mathrm{Q} \sqrt{ }\left[(\mathrm{F} / \mathrm{E})\left(\mathrm{D} / \mathrm{t}_{\text {effective }}\right) 3\right]
$$

Where,

$\mathrm{d}^{2}$ airvent $=$ internal diameter of air vent in $\mathrm{mm}$

It is already known from the survey that the maximum flow of water through turbine is $1.2 \mathrm{~m}^{3} / \mathrm{s}$, "E" is the Young's modulus for the penstock material, $\mathrm{D}$ is the diameter of the penstock and " $F$ " is the safety factor. In this case, it has been chosen as 10 because our design consists of exposed pipes. Therefore,

$\mathrm{d}^{2}$ airvent $=1200 \sqrt{ }\left[(10 / 210000)(280 / 2.78)^{3}\right]$

$=91.45 \mathrm{~mm}$. The diameter of the air vent to be constructed is therefore $92 \mathrm{~mm}$. 


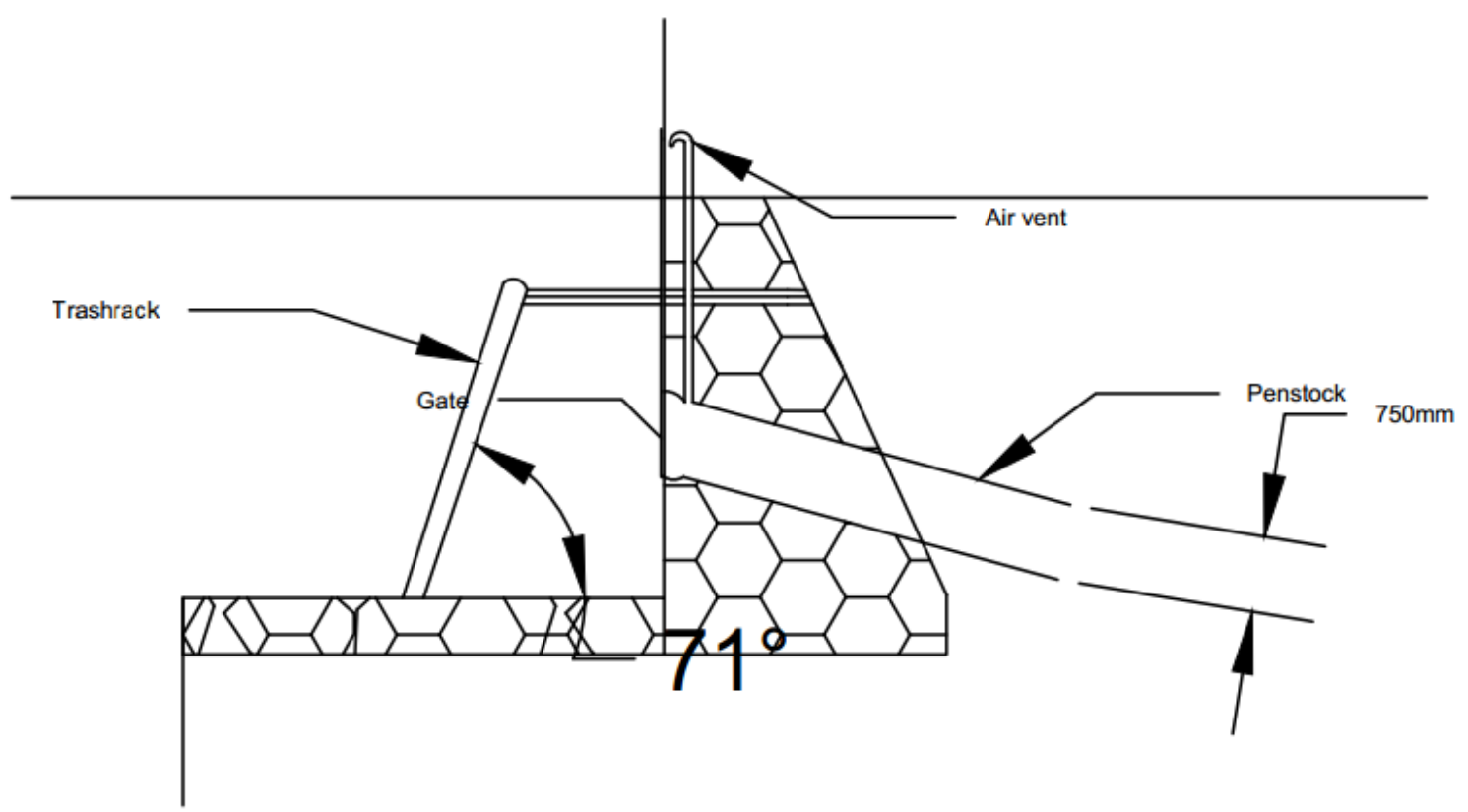

Figure 9. Design of the fore bay tank with trash rack and air vent shown (AutoCAD).

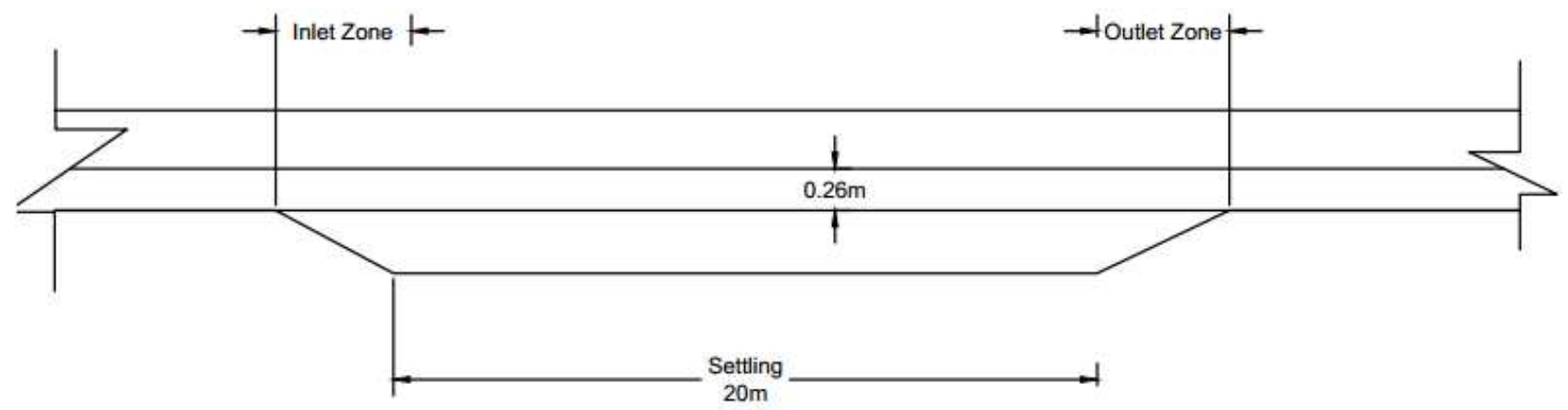

Longitudinal view of the settling basin (AUTOCAD)

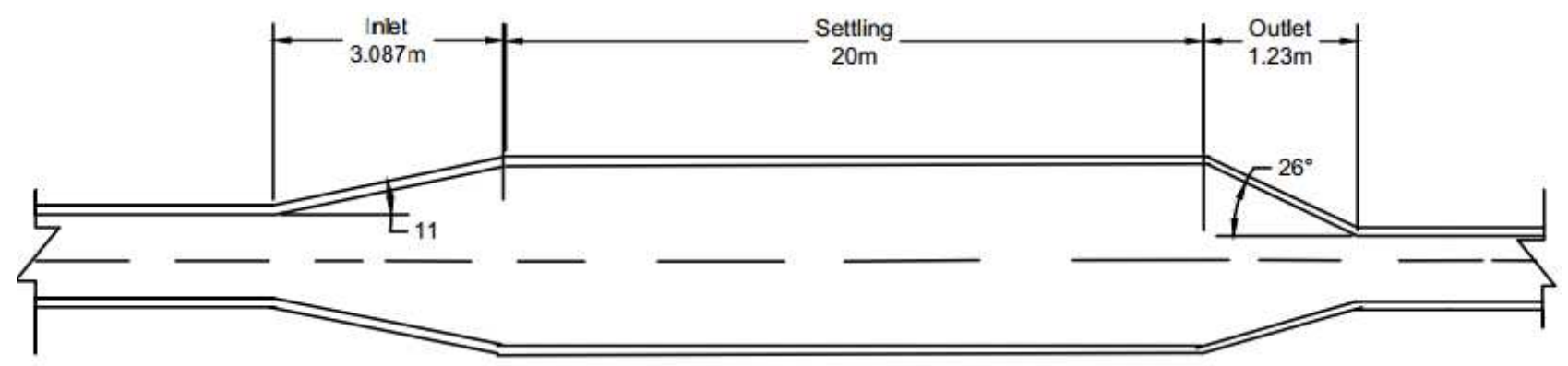

Top view of the settling basin (AUTOCAD)

Figure 10. Longitudinal view of the fore bay tank.

\subsubsection{Design of Trash Rack}

To prevent the trash from getting entry into the entrance flume, bars at certain spacing (called trash rack) are placed in a slanting position (at an angle $60^{\circ}$ to $80^{\circ}$ with horizontal). The maximum possible spacing between the bars is generally specific by the turbine manufacturers. Typical value are (20-
$30 \mathrm{~mm}$ ) for Pelton turbines, $(40-50 \mathrm{~mm})$ for Francis turbines and $(80-100 \mathrm{~mm})$ for Kaplan turbines. A screen or grill is always nearly at the entrance of both pressure pipes and intakes to avoid the entrance of floating debris. The flow of water through the rack also gives rise to a head loss. The trash rack coefficient $(K t r)$ depends on the bar shape and may be vary from (0.8) to (2.4). 


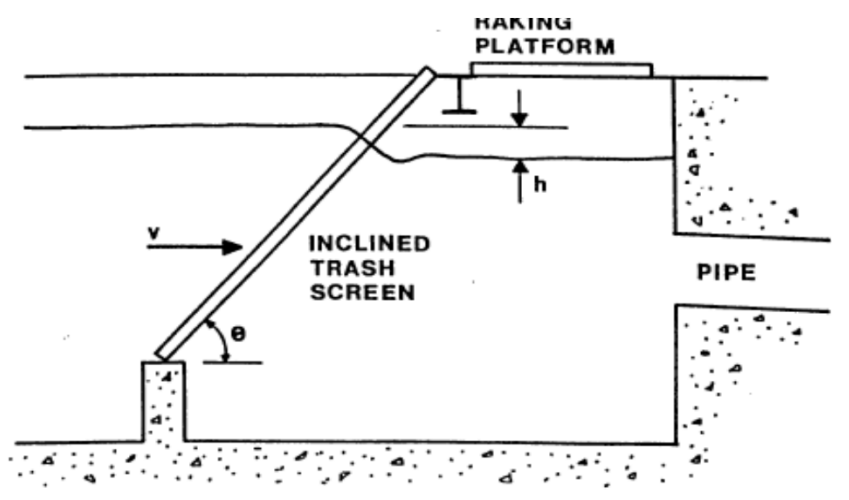

Figure 11. Trash rack.

\subsubsection{Power House}

The powerhouse of the micro/mini hydropower plant is furnished with hydro turbine, hydro power generator, distributor control panel and other auxiliary equipment; it is the last procedure to convert the hydraulic power into electricity. So powerhouse design should be reasonable, easy to operation management, compact size, and conform to the economy. We should pay attention to the following principles:

1. Power house should be settled on the position immune from immersion when rising flood.

2. Hydropower turbine and generator set installation should be firm; power house should be dry, ventilation, smooth drainage.

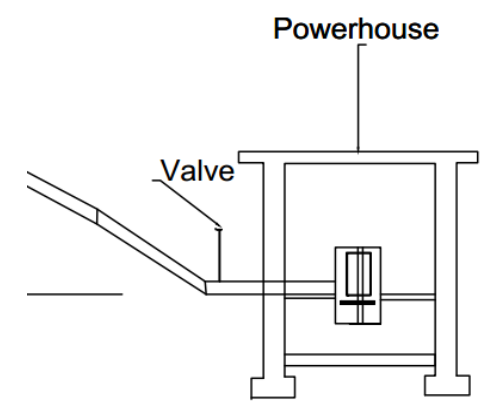

Figure 12. Design of powerhouse components from AutoCAD.

Micro/mini hydro turbine is usually small in size, small water flow, not too high head, not too big capacity, and its equipment are simple in the power house. Generally home micro hydropower generator under $1000 \mathrm{w}$, its powerhouse construction can be simple, as long as it can accommodate the equipment and protest the equipment from rain and other bad weather is enough. More than 1500 watts of power plant, you can design the power house area according to the size of the unit and convenient maintenance. If there is no automatic control device of above 30 kilowatts units, you should consider the personnel on duty room as well.

\subsubsection{Tailrace Channel of Micro/Mini hydro Generator}

Tailrace channel is the drainage channel after the hydro turbine draft tube. For micro pelton turbine and micro turgo turbine, tailrace channel function is only drain away the water from the turbine, there is no other requirement; For reaction type of micro hydro turbine (Francis turbine and axial flow or Propeller turbine or Kaplan turbine or Tubular turbine), its tailrace has certain requirements, building must be set strictly accordance with the requirements of HS Dynamic Energy or your micro hydropower turbine manufacturer and supplier, or it will be great influence on the unit output, seriously cannot generate electricity from your unit.

\subsubsection{Selection of Turbines and Its Components}

The turbine is a mechanical device that converts hydraulic power in the water into mechanical power-known as shaft power and is usually placed in the powerhouse. This shaft power is converted into electricity by the generator; thus, the turbine determines the electricity capacity of the MHP installation. The most common types of turbines for MHP application are Francis, Kaplan, Pelton Wheel, Cross flow, and Centrifugal pumps operated in turbine mode.

Type of turbine is selected from techno-economic consideration of generating equipment, powerhouse cost and relative advantage of power generation. Most of the manufacturers have developed standardized turbine designs which may be efficiently employed. Standard design may lead to cheaper and quicker construction. There are different factors, which determine the type of turbine for the given site. The factors may be head, head and load variation, efficiency and specific speed [19].

In the present study the turbine type is selected by utilizing the standard chart, which utilizes the head and power generation in determining the turbine type.

The parameters that help in the choice of turbine are tabulated below in table 5. It is primarily the head measurement that determines the selection of a suitable turbine for a particular MHS (Micro/Mini Hydropower System).

Table 5. Classification of mini/micro hydro turbines according to head, flow rate and power output.

\begin{tabular}{|c|c|c|c|c|c|}
\hline no & classification & Turbine type & Head (m) & Flow $\left(\mathrm{m}^{3} /\right)$ & Power outside (kw) \\
\hline \multirow{3}{*}{1} & \multirow{3}{*}{ Impulse turbine } & Pelton & $50-1000$ & $0.2-3$ & $50-15000$ \\
\hline & & Turgo & $30-200$ & $0.2-5$ & $20-5000$ \\
\hline & & Cross flow & $2-50$ & $0.01-2$ & $0.1-600$ \\
\hline \multirow{3}{*}{2} & \multirow{3}{*}{ Reaction turbine } & Propeller & $3-40$ & $3-20$ & $50-500$ \\
\hline & & Francis radial flow & $40-200$ & $1-20$ & $500-15000$ \\
\hline & & Francis mixed flow & $10-20$ & $0.7-10$ & $100-5000$ \\
\hline
\end{tabular}




\subsection{Environmental Impact Assessment}

Environmental Assessment is the entire process accompanying a development project proposal that determines the likely environmental impacts due to construction, operation, and closing the project. In order to make a decision whether the planned project shall be implemented or not, we should know in advance how much environmental impacts are expected to occur due to its implementation.

Hydropower plant produces environmental and related social effects i.e. hydrological effect, landscape effect, and social effect.

\subsubsection{Hydrological Effect}

This is significantly affecting the ecology of a land and for the local community, especially in the case of a large scale installation. The diversion of a mountain stream in to a pipe does not, may be seriously change the flow at the valley bottom but it will have a noticeable effect on the intermediate levels. Storing part of the water in a reservoir is another problem since it may reduce the final flow as a result of evaporation from a large exposed surface. In addition to this ground water is reduced to a hydropower plant the surrounding countryside might cause suffer a number of changes and impacts which might affect the economy and the ecology.

\subsubsection{Landscape}

The erection of hydropower plant may affect the landscape. The process itself causes disturbance even the building period lasts only a few years. The disturbances are magnified when the construction timetable is not met, as is often the case with large-scale hydropower plant.

\subsubsection{Social Effects}

In general hydropower plant has positive and negative effects; there are people who have benefits of this and other pay for this. The construction of dams may have very different consequences on the people immediately affected. The effect of hydropower on human health is the most significant, especially in countries where the possibility of the spreading of diseases such as malaria. The other social effect is the displacement of people living in villages, which are to become water reservoirs. Historically, on a lot of occasions thousands of people were forced to move from their house in order for a hydropower plant to be erected

\section{Results and Discussions}

\subsection{Estimation of Discharge}

The design discharge was estimated based on the flow duration curve of the Keber River and the demand of the community. In addition to the above factors there is also another guideline which shows the limit of discharge and head where the mini hydropower is going to be feasible. So based on these constraints the design discharge was estimated to be $1.2 \mathrm{~m}^{3} / \mathrm{s}$. It was also estimated that the head difference between the fore-bay tank and the power house was $12 \mathrm{~m}$. This head difference was measured using GPS during the field survey. The site for the weir, fore-bay tank and power house was also determined during the field survey.

The general layout of the keber river mini hydropower plant was set as shown below.

\subsection{Power Estimation}

The available power is the sum of the power output and the loss through the channel, penstock, turbine, generator and the line. The power input, or the power absorbed by the hydropower scheme is the gross power and the power usually delivered is the net power.

From the general formula given below the power can be estimated.

$$
\mathrm{P}=\rho \mathrm{QgH} \eta о
$$

Where: $\mathrm{P}=$ Electric power output $\left(\mathrm{W}=\mathrm{N}^{*} \mathrm{~m} / \mathrm{s}\right)$

$\mathrm{g}=$ gravitational acceleration $\left(\mathrm{m} / \mathrm{s}^{2}\right)$

$\rho=$ density $\left(\mathrm{kg} / \mathrm{m}^{2}\right)$

$\mathrm{Q}=$ Design Flow rate $\left(\mathrm{m}^{3} / \mathrm{s}\right)$

$\mathrm{H}=$ Hydraulic Head (m)

$\eta_{0}=$ Generation efficiency

But, $\eta$

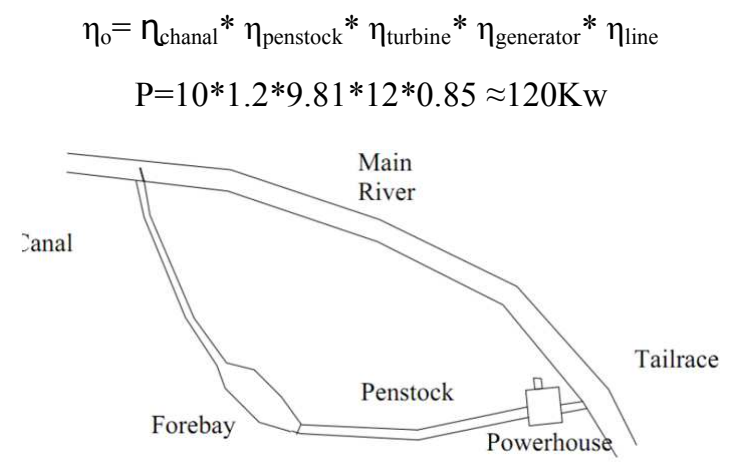

Figure 13. General layout of the Keber mini hydropower plant.

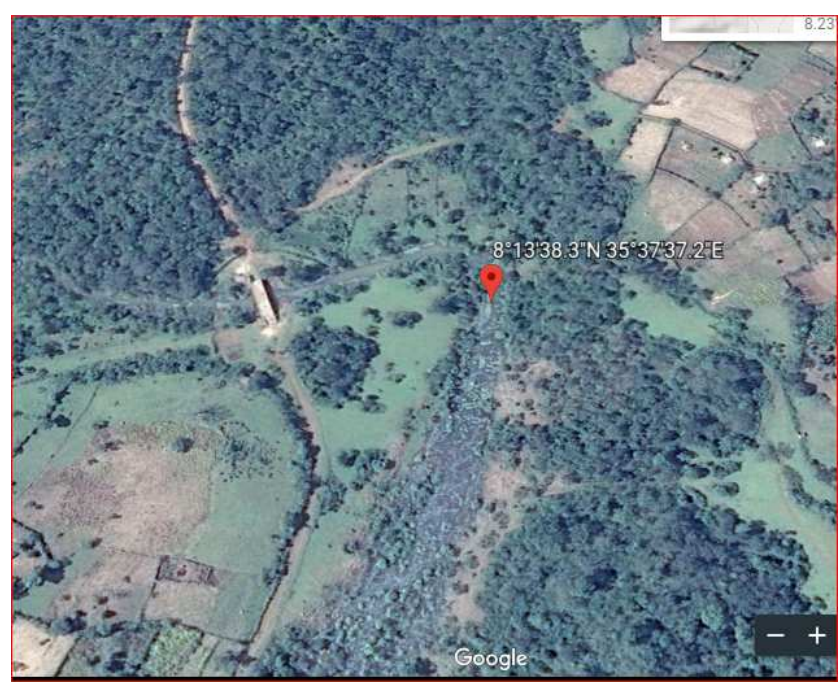

Figure 14. Weir site as taken from the Google earth. 
Based on the field survey the canal length was measured to be around $500 \mathrm{~m}$ and the penstock length was around $20 \mathrm{~m}$. The design of these and other civil structures such as forebay tank and canal dimensions was made as explained in chapter three.

Capacity Factor

Capacity factor is the ratio of energy used and the available energy from the mini hydropower plant. In the village there are 300 households and assuming each will have three lamps taking $60 \mathrm{~W}$ power functional for five hours each, radio/tape recorder and a small fun taking $20 \mathrm{~W}$ and $50 \mathrm{~W}$ respectively functional for 10 hours, a small TV set of 120 wattage rating used for 6 hours a day and a 3 small health clinic with consumption of $10 \mathrm{kwh}$ per day.

Capacity factor $=$ Energy used/Energy available

$$
\begin{gathered}
C F=\frac{[(0.06 \mathrm{kw} * 3 * 5 \mathrm{~h}+0.02 \mathrm{kw} * 1 * 10 \mathrm{~h}+0.05 \mathrm{kw} * 1 * 10 \mathrm{~h}+0.12 \mathrm{kw} * 1 * 6 \mathrm{~h}) * 300+3 * 10 \mathrm{kwh} / \mathrm{day}]}{120 \mathrm{kw} * 12 \mathrm{~h}} \\
\mathrm{CF}=0.5
\end{gathered}
$$

Daily energy consumption is computed based on the utilization of each house hold utensils, which is computed as below:

$$
\begin{aligned}
=0.06 \mathrm{kw}^{*} 3 * 5 \mathrm{~h}+ & 0.02 \mathrm{kw}^{*} 1 * 10 \mathrm{hr}+0.05 \mathrm{kw}^{*} 1 * 10 \mathrm{hr} \\
+ & 0.12 \mathrm{kw} * 1 * 6 \mathrm{hr} \\
= & 2.32 \mathrm{kwh}=2320 \mathrm{wh}
\end{aligned}
$$

Annual energy production of the plant can be calculated as:

$$
=120 \mathrm{kw} \times 8760 \times 0.50=525.6 \mathrm{MWh} / \text { year }
$$

The annual energy consumption of the village can be calculated as:

$$
\begin{gathered}
\text { Required energy }=2320 \mathrm{Wh} / \text { day X } 30 \text { day/month X } 12 \\
\text { months/year x } 300 \text { households } \\
+30 \mathrm{kwh} / \text { day*30day/month*12months/year } \\
=250.56 \mathrm{MWh} / \text { Year }+10.8 \mathrm{MWh} / \text { Year } \\
=261.36 \mathrm{MWh} / \text { Year }
\end{gathered}
$$

Hence $264.24 \mathrm{MWh} /$ year is extra energy and the residents may use this energy for other essential works.

\subsection{Selection of Turbines}

The gross head of the proposed Hydropower is $12 \mathrm{~m}$ and the design discharge is $1.2 \mathrm{~m}^{3} / \mathrm{s}$. So based on these parameters (i.e. as the criteria's set for selection of turbine based on head available, design discharge and power output in chapter three) the appropriate turbine for this plant is Cross flow turbine

\subsection{Civil Components}

Based on the field survey data that had been taken on the site, the study dealt with designing the major civil components for the keber Mini Hydro project in Tobacha kebele. Based on the design parameters, the calculations carried out helped to determine critical dimensions of the civil components of the Keber Mini Hydro Project. The critical dimensions of various components are summarized in Table 6 below.
Table 6. Summary of the critical dimensions of civil components of Keber mini hydropower project.

\begin{tabular}{ll}
\hline Components & Critical Dimensions \\
\hline Dimensions of Orifice & Design flood level $=1.2 \mathrm{~m} / \mathrm{s}$ \\
for side intake & Area of orifice $=0.8 \mathrm{~m}$ \\
& Cross sectional area $=1.2 \mathrm{~m} / \mathrm{s}$ \\
& Optimum canal height $=0.77 \mathrm{~m}$ \\
& Canal bed width $=1.16 \mathrm{~m}$ \\
& Canal Top width $=1.93 \mathrm{~m}$ \\
Dimensions of head & Critical velocity $=6 \mathrm{~m} / \mathrm{s}$ \\
race canal & Wetted perimeter $=2.88 \mathrm{~m}$ \\
& Head loss $=0.465 \mathrm{~m}$ \\
& Hydraulic radius $=0.416 \mathrm{~m}$ \\
& Canal bed slope $=0.00092$ \\
& Length $=20 \mathrm{~m}$ \\
Dimensions of fore bay & Submergence head $=0.48 \mathrm{~m}$ \\
& Diameter of air vent $=91.45 \mathrm{~mm}$ \\
& Material $=$ steel \\
& Length $=20 \mathrm{~m}$ \\
Dimensions of & Pipe diameter $=750 \mathrm{~mm}$ \\
penstock assembly & Total head loss $=0.213 \mathrm{~m}$ \\
\hline
\end{tabular}

\subsection{General Layout}

The general layout of Keber mini hydropower includes weir, canal, forebay, penstock, the power house and tail race.

\section{Conclusion}

Hydropower, large and small, remains by far the most important of the "renewables" for electrical power production worldwide. Small-scale hydro including Mini, Micro and Pico is in most cases "run-of-river", with no dam, and is one of the most cost-effective and environmentally kind energy technologies to be considered both for rural electrification in less developed countries and developed countries for further hydro developments. As the cross-flow turbine is suitable for installing small hydro-electric power plants in case of low head and flow rate similarly in Keber this type of turbine was selected for the development.

A $120 \mathrm{~kW}$ mini hydro power plant has been designed for rural electrification at the Keber site in the Ilu Aba Bora zone of Mettu woreda Tobecha kebele. The proposed mini hydro power plant is found to be technically viable and it not only 
meets the energy demand of about 300 households in the locality but also improves their living standard as the operation and maintenance of the plant would be managed by them.

Altogether the study showed that construction of MHP (Mini Hydro Project) was feasible in the project site and there were no major problems apparent at least at the design stage of the mini hydro project.

The practical design of various components that were conducted in this research led to the realization that the design of the system components is very much determined by the location specific factors. From the very beginning, the MHP (Mini Hydro Project) designed was constrained to being "run of the river" type, because the river Source, Keber, is situated in a good topographical region for the development of such projects. Similarly, in the design of headrace canal and forebay tank, the choice of materials were already determined by their availability and local topographical conditions. For example, the choice of stone masonry with cement mortar type of canal for the headrace was considered because in the topographically hilly and rainy areas, mud mortar type, for example would have led to seepage of water from the canal and so would have caused landslide in the longer run which is not considered desirable.

\section{References}

[1] Abebe, N., 2014. Feasibility Study of Small Hydropower Schemes in Giba and worie subbasins of Tekeze River, Ethiopia. Energy Technology polic, Volume 4, pp. 8-17.

[2] Adejumobi et al., I. a. A. O., 2011. Exploring small hydropower potentials for domestic and Information communication technology infrastructural application in rural communities in Nigeria.. Proceeding of the 12th Biennial International conference of Botswana Institution of Engineers, pp. 19-26.

[3] AHEC-IITR, 2013. project hydrology and installed capacity standard/manual/guideline with support from ministry of new and renewable energy. p. 37.

[4] Anyaka, B. O., 2013. small hydropower projects for rural electrification in Nigeria. Volume A.

[5] bereou, D. o. E. d., 2009. project evaluation guideline for development of microhydropower development.

[6] Capik et al., M. Y. A. a. C., 2012. Hydropower for sustainable energy development in Turkey: the small hydropower case of the Eastern Black Sea Region, s.1.: s.n.

[7] Chitrakar, P., 2004. Micro-Hydropower Design Aids Manual:
Kathmandu: small hydropower promotion project (SHPP/GTZ) and mini-grid support programme (MGSP/AEPC-ESAP), s.l.: s.n.

[8] Dawit, H. M., 2010. Ethiopian Energy Systems: Potentials, Opportunities and Sustainable Utilization. Uppsala, Sweden: s.n.

[9] Derbew, D., 2013. Ethiopia's Energy Power Potential and Development Opportunities,. [Online] Available at: http://www.irena.org/DocumentDownloads/events/2013/July/ Africa $\% 20$ CEC $\% 20$ session $\% 203$ Ministr [Accessed 1211 2018].

[10] Embassy of Japan in Ethiopia., 2008. Study on the Energy Sector in Ethiopia. [Online] Available at: http://www.et.embjapan.go.jp/electric_report_english.pdf [Accessed 1208 2018].

[11] Energypedia., 2008. Ethiopia Conditions for Pico/Mini Hydro Power Grid Connection. [Online] Available at: https://energypedia.info/images/8/87/Feedin_study_ethiopia_-_001-084.pdf [Accessed 237 2018].

[12] ESHA, (. s. H. A., 2004. Guide on how to develop a small hydropower plant. [Online] Available at: http://www.esha.be/fileadmin/eshafiles/documents/publication s/Guides/guideshp/guide shp en.pdf.[Accessed 1505 2018].

[13] ESHA, (. S. H. A., 2004. Guiede on how to develope a small hydropower plant. [Online] [Accessed 2016].

[14] Feibel, D., 2013. An Interdisciplinary ApproachAn Interdisciplinary Approach to the Dissemination of Mini and Micro Hydropower -the case of Ethiopia, Technische Universität Darmstadt: s.n.

[15] FMCAG, (. M. c., 2014. Hydroelectric power: A guide for developers and investors. p. 120.

[16] Foster, V., 2010. Ethiopia's Infrastructure: A Continental Perspective. [Online] Available at: http://www.infrastructureafrica.org/system/files/library/2009/1 1/CR\%20Ethiopia.pdf [Accessed 1208 2018].

[17] Foundation Rockefeller., n.d. Pico-hydro power a pro-poor solution to electricity demands. [Online] Available at: http://www.searchlightcatalysts.org/node/215/Tools [Accessed 0909 2018].

[18] Fritz, J., 1984. Small and Mini hdyropower systems, Resource Assessment and project feasibility, USA: McGraw-Hill Book Company.

[19] Nehimia Solomon, (2005). Identification and Engineering Geological Studies of Small Hydropower sites in Muger, Jemma and Waleks Sub-basins (Central Ethiopia), MSc Thesis (Unpublished), Department of Earth sciences, Addis Ababa University.Project Feasiblity. USA: s.n. 